\title{
Partial characterization of esterases from Fusarium culmorum grown in media supplemented with di (2-ethyl hexyl phthalate) in solid-state and submerged fermentation
}

\section{Caracterización parcial de esterasas de Fusarium culmorum crecido en presencia de di(2-etil hexil ftalato) en fermentación sólida y sumergida}

Lorena Ferrer-Parra ${ }^{2}$, Dolores Itzel López-Nicolás ${ }^{3}$, Rocío Martínez-Castillo ${ }^{4}$, Juan Pedro Montiel-Cina ${ }^{5}$, Ana Rosa Morales-Hernández ${ }^{6}$,Edgardo Ocaña-Romo ${ }^{7}$, Angel GonzálezMárquez $^{8}$, Monserrat Portillo-Ojeda ${ }^{9}$, Dania Fernanda Sánchez-Sánchez ${ }^{10}$, Carmen Sánchez ${ }^{1 *}$

${ }^{1}$ Laboratory of Biotechnology, Research Centre of Biological Sciences, Universidad Autónoma de Tlaxcala, Ixtacuixtla, Tlaxcala C.P. 90062, México.

${ }^{2}$ Licenciatura en Biología (BSc student), Universidad Autónoma de Nayarit, Tepic, Nayarit, México.

${ }^{3}$ Licenciatura en Biotecnología (BSc student), Universidad Autónoma del Estado de México, Toluca de Lerdo, Estado de México, México.

${ }^{4}$ Licenciatura en Ciencias Ambientales (BSc student), Universidad Autónoma del Estado de México, Toluca de Lerdo, Estado de México, México.

${ }^{5}$ Licenciatura en Químico Farmacéutico Biólogo (BSc student), Universidad Autónoma de Tamaulipas, Reynosa, Tamaulipas, México.

'Ingeniería Bioquímica (BSc student), Instituto Tecnológico Superior de los Ríos, Tabasco, México.

${ }^{7}$ Ingeniería en Sistemas Ambientales (BSc student), Instituto Politécnico Nacional, Ciudad de México, México.

${ }^{8}$ Doctorado en Biotecnología, Universidad Autónoma Metropolitana-Iztapalapa, Ciudad de México, México.

${ }^{9}$ Licenciatura en Biología (BSc student), Facultad de Estudios Superiores-Zaragoza, Universidad Nacional Autónoma de México, Ciudad de México, México.

${ }^{10}$ Ingeniería en Biotecnología (BSc student), Universidad Politécnica de Tlaxcala, Tlaxcala, México.

*Corresponding author.

E-mail address: sanher6@ hotmail.com (C. Sánchez).

Article history:

Received: 31 August 2017 / Received in revised form: 14 November 2017 / Accepted: 10 December 2017 / Published online: 1 January 2018.

https://doi.org/10.29267/mxjb.2018.3.1.84 


\begin{abstract}
Di (2-ethylhexyl) phthalate (DEHP) is a plasticizer used in the polyvinyl chloride (PVC) industry. The indiscriminate use of various products manufactured with PVC, causes this plasticizer to be considered a contaminant. Fusarium culmorum is a phytopathogenic fungus that has the ability to produce esterase enzymes. Esterases are of great importance because they can break the ester bonds present in the plasticizers. In this work, the activity of esterases produced by $F$. culmorum grown in media supplemented with different concentrations of DEHP (1500 and $2000 \mathrm{mg} / \mathrm{L})$ in solid-state fermentation and submerged fermentation was characterized by biochemical tests and polyacrylamide gel electrophoresis. F. culmorum showed higher esterase activity in media supplemented with 1500 and $2000 \mathrm{mg}$ DEHP/L in solid-state fermentation. A greater number of esterase activity bands were observed in the DEHP-supplemented media, having a molecular weight of about 20, 25, 37, 45, 55, 75 and $150 \mathrm{kDa}$, in both fermentation systems. $1500 \mathrm{mg}$ of DEHP/L induced a higher production of esterases, demonstrating that high concentrations of DEHP did not inhibit the enzymatic production of the fungus.
\end{abstract}

Keywords: F. culmorum, di (2-ethyl hexyl) phthalate, esterases, submerged fermentation, solid fermentation.

\title{
RESUMEN
}

Di(2-etilhexil) ftalato (DEHF) es un plastificante utilizado en la industria del policloruro de vinilo (PVC). El uso indiscriminado de los diversos productos elaborados con PVC, ocasiona que éste plastificante sea considerado un contaminante. Fusarium culmorum es un hongo fitopatógeno que tiene la capacidad de producir enzimas esterasas. Las esterasas son de gran importancia debido a que pueden romper los enlaces ésteres presentes en los plastificantes. En este trabajo se caracterizó parcialmente la actividad de esterasas producidas por $F$. culmorum crecido en presencia de diferentes concentraciones de DEHF (1500 y $2000 \mathrm{mg} / \mathrm{L}$ ) en fermentación sólida y fermentación sumergida, a través de ensayos bioquímicos y electroforesis en gel de poliacrilamida. F. culmorum presentó mayor actividad de esterasas en los medios con 1500 y 2000 mg de DEHF/L en fermentación sólida. Se observaron mayor número de bandas de actividad de esterasas en los medios adicionados con DEHF, de un peso molecular aproximado de 20, 25, 37, 45, 75 y $140 \mathrm{kDa}$, en ambos sistemas de fermentación. $1500 \mathrm{mg}$ de DEHP/L indujó una mayor producción de esterasas, demostrando que concentraciones elevadas de DEHF no inhiben la producción enzimática del hongo.

Palabras clave: di (2-etil hexil) ftalato, esterasas, F. culmorum, fermentación sumergida, fermentación sólida. 


\section{INTRODUCTION}

Di (2-ethylhexyl) phthalate (DEHP) is a chemical compound that is added as an additive in order to make plastics more flexible. This compound is present in various plastic products, especially in manufactured materials that are made of polyvinyl chloride, such as blood bags, food packages, and toys, which can contain up to $40 \%$ of DEHP. However, these products usually contain lower levels than this. DEHP chemical base is the dicarboxylic benzene acid with two lateral chains that can be alkyl, benzyl, phenyl, cicloalkyl or alcoxi groups (Daiem et al., 2012; Gao \& Wen, 2015).

The widespread use of the plasticizer in various industries is the reason why it is released into the environment (Aguilar-Alvarado et al., 2015). The DEHP does not form part of the molecular chain that constitutes the plastic, being liberated from plastic matrix to the environment. In this way, it can be released into the environment and to cause environmental pollution (Meng, 2015).

It has been reported that the filamentous fungi Fusarium soliani, f. sp. Pisi, Pseidozymajejuensis sp. Nov, Aspergillus oryzae have the capacity to produce cutinases enzymes that hydrolyze the soluble esters (Castro-Ochoa et al., 2010; Adame-García et al., 2011). In the case of the phytopathogenic fungi, this mechanism helps the fungus to degrade the cutinase from the cellular wall of plants and use the nutrients from the structure of the cellular wall, such as hemicellulose and pectin for its growth. The ability of the organisms to secrete enzymes makes them the most useful tool in nature for degrading complex compounds. Therefore, it is important to find organisms with the ability to produce esterases that can be employed for the degradation of phthalates, through the rupture of the ester bonds present in these compounds.

Aguilar-Alvarado et al. (2015) isolated the fungus Fusarium culmorum from a paper recycling industry and found that it was able to degrade high concentrations of DEHP. $F$. culmorum is a phytopathogenic fungus that has been studied for its capacity to produce esterases enzymes and to degrade DEHP.

In this work, the esterases enzymatic activity produced by $F$. culmorum grown in presence of different concentrations of DEHP (1500 and $2000 \mathrm{mg} / \mathrm{L}$ ) in solid-state fermentation and submerged fermentation was evaluated. The molecular weight of the enzymes was also determined using polyacrylamide electrophoresis gel. 


\section{MATERIAL AND METHODS}

\subsection{Organism}

F. culmorum from the Research Centre for Biological Sciences (CICB) culture collection at Universidad Autónoma de Tlaxcala (Tlaxcala, Mexico) was used. The strain grew in Czapek medium at $25^{\circ} \mathrm{C}$ and was preserved in refrigeration at $4{ }^{\circ} \mathrm{C}$.

\subsection{Submerged fermentation and solid-state fermentation}

Three culture media were carried out as follows; 1) $10 \mathrm{~g}$ glucose/L, 2) $1500 \mathrm{mg} \mathrm{DEHP} / \mathrm{L}$ and 3) $2000 \mathrm{mg} \mathrm{DEHP/L}$. Each culture medium contained (in $\mathrm{g} / \mathrm{L}$ ): $\mathrm{NaNO}_{3}, 3$; $\mathrm{KCl}, 0.5$; $\mathrm{K}_{2} \mathrm{HPO}_{4}, 1.0 ; \mathrm{FeSO}_{4}, 0.01$. Media supplemented with DEHP were added with $400 \mu \mathrm{L}$ of Tween 80 per liter. The $\mathrm{pH}$ of the medium was adjusted to 7.5, employing either $\mathrm{NaOH}$ $0.1 \mathrm{M}$ or $\mathrm{HCl} 0.1 \mathrm{~N}$. Flasks of $150 \mathrm{~mL}$ containing culture medium $(50 \mathrm{~mL})$ were autoclaved at $120^{\circ} \mathrm{C}$ for 15 minutes and then used for submerged fermentation experiments. Flasks of $250 \mathrm{~mL}$ containing $0.5 \mathrm{~g}$ of polyurethane foam (PUF) cut in cubes $\left(0.5 \mathrm{~mm}^{3}\right)$ as inert support soaked in $15 \mathrm{~mL}$ of sterile culture medium were used for solid-state fermentation studies. The cubes were previously washed twice with distilled water and then placed in $\mathrm{NaOH}$ and $\mathrm{HCl}$ solutions $(0.1 \mathrm{~N})$, for 24 hours in each solution, dried in oven at $40^{\circ} \mathrm{C}$ and autoclaved at $120^{\circ} \mathrm{C}$ for 15 minutes. In all the cases, the flasks were inoculated with three mycelium fragments of $10 \mathrm{~mm}$ diameter taken from the periphery of the colonies grown for 7 days. Flask were incubated during 8 days at $25^{\circ} \mathrm{C}$. For submerged fermentation studies, flask were incubated at $120 \mathrm{rpm}$. In all cases, the samples were taken each 12 hours during 8 days and the studies were performed in triplicate.

\subsection{Esterases Assay}

In all the cultures, esterases activity was assessed in the supernatant obtained from the filtration of the samples. Esterase activity was determined from changes in the absorbance at $405 \mathrm{~nm}$ using a Jenway 6405UV/Vis spectrophotometer (NJ, USA) with $p$-nitrophenyl butyrate $(p N P B)$ as substrate. The reaction mixture contained $100 \mu \mathrm{L}$ of supernatant and $900 \mu \mathrm{L}$ of reagent prepared with the following components: $1.76 \%(\mathrm{v} / \mathrm{v}) p \mathrm{NPB}, 1.11 \%$ (v/v) acetonitrile, $0.04 \%(\mathrm{v} / \mathrm{v})$ Triton X-100 and $11.11 \%(\mathrm{v} / \mathrm{v})$ distilled water, dissolved in $0.01 \mathrm{M}$ phosphate buffer at $\mathrm{pH} 7.5$ and was incubated at $37^{\circ} \mathrm{C}$ for $5 \mathrm{~min}$. One enzymatic unit of esterase activity (U) was defined as the amount of enzyme that produces an increase of 1 unit of absorbance per min in the reaction mixture (Ahuactzin-Pérez et al., 2016). The enzymatic activities were expressed in U/L.

\subsection{Enzymatic yield parameters}

Yield of enzyme per unit of biomass produced by the fungus $\left(Y_{E / X}\right)$ was estimated as the relation between maximal enzymatic activity obtained during the exponential growth $\left(E_{\max }\right)$. Enzymatic productivity $\left(P=E_{\max } /\right.$ time $)$ was evaluated at the time when the enzymatic activity was maximal (Ahuactzin-Pérez et al., 2016). 


\subsection{Zymographic analysis}

Zymography is an electrophoretic method for measuring proteolytic activity. The polypeptide profiles of the samples with esterase activity were analyzed using $0.1 \%$ polyacrylamide gels with sodium dodecyl sulfate (SDS-PAGE) (Laemmli, 1970). 12\% and $4 \%$ acrylamide gels were used as separation and packaging gels, respectively. ProteinTM Dual Precision Xtra Plus Standards (Bio-Rad) was used as molecular marker. Samples were tested on gels of $0.75 \mathrm{~mm}$ in a Mini Protean electrophoresis system Tetra Cell (Bio-Rad) at 100 volts for $1.30 \mathrm{~h}$. Subsequently, gels were incubated for 3 hours at room temperature in a solution containing $3 \mathrm{mM}$ of $\alpha$-naphthyl acetate, $1 \mathrm{mM}$ Fast Red TR (Sigma) and phosphate buffer $100 \mathrm{mM}$ at pH 7.5 (Karpushova et al., 2005). Finally, esterase activity was detected by the appearance of red-colored bands in the gels.

\subsection{Statistical analysis}

All experiments were carried out in triplicate. Data was evaluated using one-way ANOVA and Tukey post-test using Sigma Plot Version 12.0 (Systat Software Inc.).

\section{RESULTS}

\subsection{Esterases activity in cultures grown in submerged fermentation}

Figure 1 shows esterases enzymatic activity of $F$. culmorum grown in submerged fermentation. The media added with DEHP showed more esterases activity compared to the control medium (added with glucose). The greatest esterases enzymatic activity (350.8 U/L) at 180 hours was observed when medium was supplemented with $2000 \mathrm{mg}$ of DEHP/L. Table 1 shows that $F$. culmorum presented the greatest $\mathrm{Y}_{\mathrm{E} / \mathrm{X}}$ and $\mathrm{E}_{\max }$ in the medium containing $2000 \mathrm{mg}$ of DEHP/L compared to the rest of the media tested. $F$. culmorum showed the greatest $P$ in the media containing DEHP. 


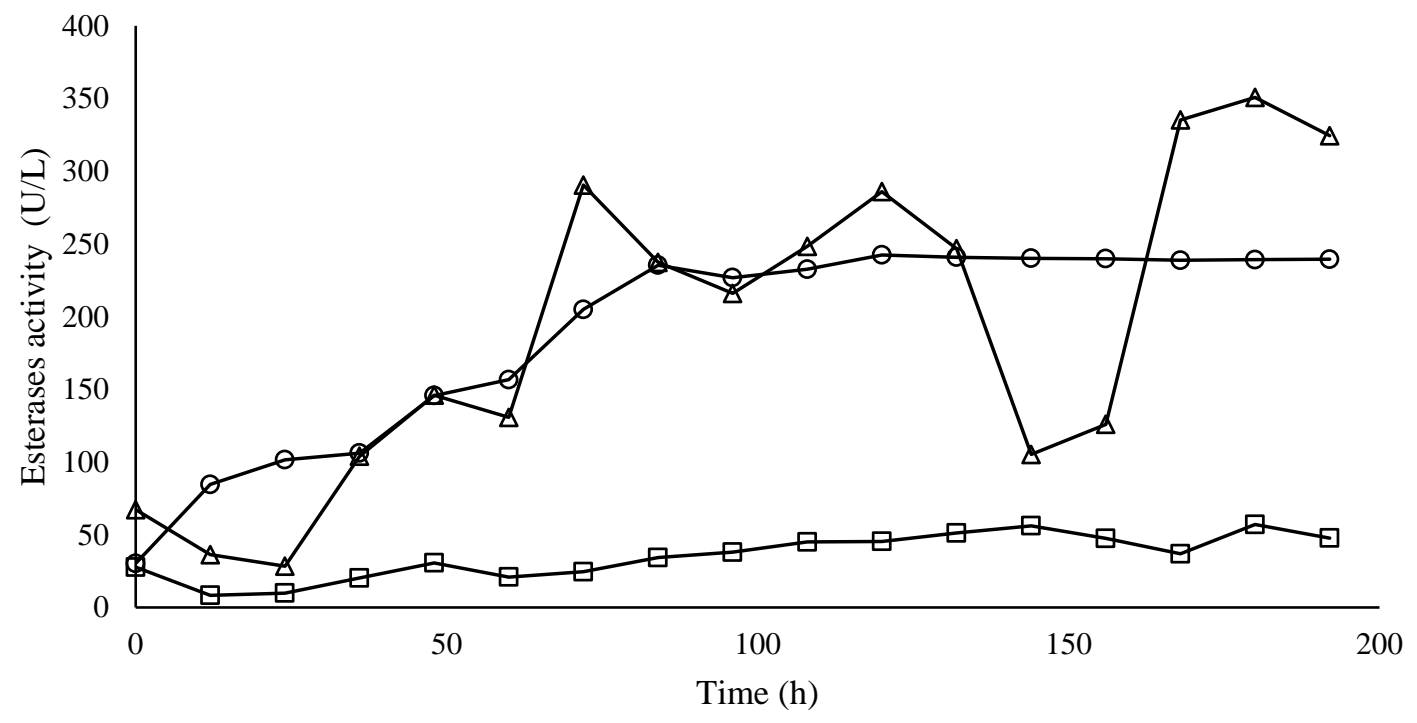

Fig. 1. Esterase activity of $F$. culmorum grown in glucose ( $\square), 1500(\circ)$ and $2000(\Delta) \mathrm{mg}$ of $\mathrm{DEHP} / \mathrm{L}$ in submerged fermentation.

Table 1. Enzymatic yield parameters of esterase of $F$. culmorum grown in media supplemented with glucose and different concentrations of DEHP in submerged fermentation.

\begin{tabular}{|c|c|c|c|}
\hline \multirow[b]{3}{*}{$\begin{array}{l}\text { Enzymatic yield } \\
\text { parameters }\end{array}$} & \multicolumn{2}{|c|}{ Culture media } & \\
\hline & \multirow[b]{2}{*}{ Glucose } & \multicolumn{2}{|c|}{ DEHP $(\mathrm{mg} / \mathrm{L})$} \\
\hline & & 1500 & 2000 \\
\hline $\mathbf{Y}_{\mathrm{E} / \mathbf{X}}(\mathrm{U} / \mathrm{gX})$ & $27.0 \pm 0.4^{\mathrm{c}^{*}}$ & $67.5 \pm 0.8^{b}$ & $168.6 \pm 1.12^{\mathrm{a}}$ \\
\hline $\mathbf{E}_{\max }(\mathbf{U} / \mathbf{L})$ & $57.1 \pm 0.6^{\mathrm{b}}$ & $242.4 \pm 1.15^{\mathrm{b}}$ & $350.8 \pm 4.2^{\mathrm{a}}$ \\
\hline$P(\mathbf{U} / \mathbf{L} / \mathbf{h})$ & $0.3 \pm 0.001^{\mathrm{b}}$ & $2.0 \pm 0.005^{\mathrm{a}}$ & $1.9 \pm 0.003^{\mathrm{a}}$ \\
\hline \multicolumn{4}{|c|}{$\begin{array}{l}\text { *Values are expressed as mean } \pm \mathrm{SD}(\mathrm{n}=3) \text {; means within the same column not sharing common superscript letters }(\mathrm{a}-\mathrm{c}) \\
\text { differ significantly at } 5 \% \text { level. }\end{array}$} \\
\hline \multicolumn{4}{|c|}{ 3.2. Esterases activity in cultures grown in solid-state fermentation } \\
\hline \multicolumn{4}{|c|}{$\begin{array}{l}\text { The DEHP supplemented media showed greater enzymatic activity compared to the control } \\
\text { medium (Fig. 2). The medium containing } 1500 \mathrm{mg} \text { DEHP/L showed an activity of } 448.1 \\
\text { U/L and the medium containing } 2000 \mathrm{mg} / \mathrm{L} \text { showed esterases enzymatic activity of } 420.2 \\
\text { U/L. Table } 2 \text { shows that } F \text {. culmorum presented greater Emax y P in the media containing } \\
\text { DEHP than the control medium. The greatest } \mathrm{Y}_{\mathrm{E} / \mathrm{X} \text { was observed in the medium containing }} \\
1500 \mathrm{mg} \text { DEHP/L. }\end{array}$} \\
\hline
\end{tabular}




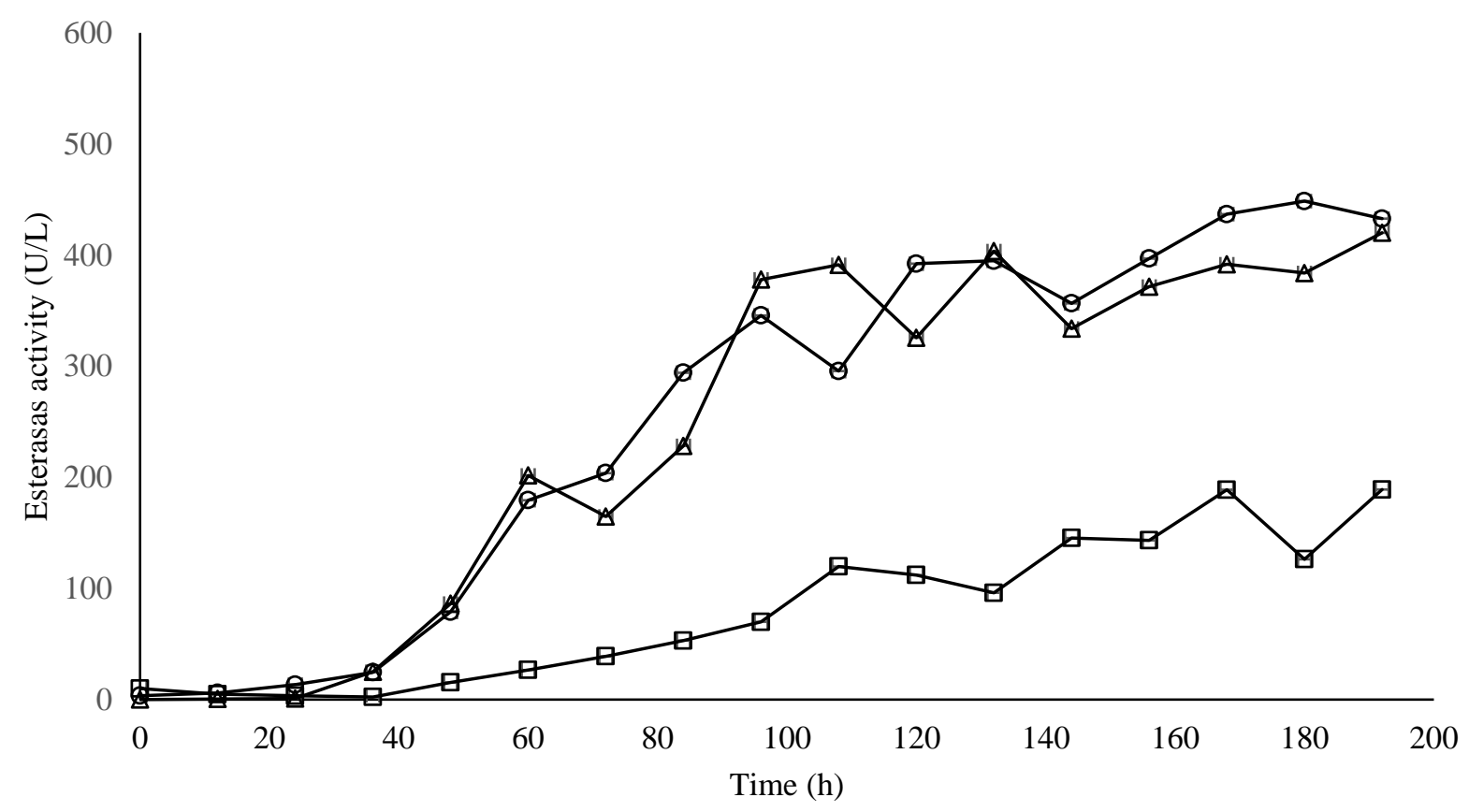

Fig. 2. Esterase activity of F. culmorum grown in Glucose ( $\square), 1500(\circ)$ and $2000(\Delta) \mathrm{mg}$ DEHP/L in solid-state fermentation.

Table 2. Enzymatic yield parameters of esterase of $F$. culmorum grown in media supplemented with glucose and different concentrations of DEHP in solid-state fermentation

\begin{tabular}{lcrr}
\hline $\begin{array}{l}\text { Enzymatic yield } \\
\text { parameters }\end{array}$ & \multicolumn{1}{c}{ Culture media } \\
& Glucose & 1500 & DEHP (mg/L) \\
& & $50.3 \pm 0.7^{\mathrm{a}}$ & $42.8 \pm 0.6^{\mathrm{b}}$ \\
$\mathbf{Y}_{\mathbf{E} / \mathbf{X}}(\mathbf{U} / \mathbf{g X})$ & $36.4 \pm 0.5^{\mathrm{c}^{*}}$ & $448.6 \pm 2.9^{\mathrm{a}}$ & $420.1 \pm 2.9^{\mathrm{a}}$ \\
$\mathbf{E}_{\max }(\mathbf{U} / \mathbf{L})$ & $189.0 \pm 1.0^{\mathrm{b}}$ & $2.5 \pm 0.005^{\mathrm{a}}$ & $2.2 \pm 0.004^{\mathrm{a}}$ \\
$\boldsymbol{P}(\mathbf{U} / \mathbf{L} / \mathbf{h})$ & $1.0 \pm 0.001^{\mathrm{b}}$ & & \\
\hline *Values are expressed as mean \pm SD $(\mathrm{n}=3) ;$ means within the same column not sharing common superscript letters (a-c) \\
differ significantly at 5\% level.
\end{tabular}

\subsection{Zymographic analysis in cultures grown in submerged fermentation}

Figure 3 shows the zymogram of the medium that contained glucose as carbon source. A band with esterase activity was observed after $12 \mathrm{~h}$ with a molecular weight of $45 \mathrm{kDa}$ approximately, which was observed during the fermentation. Bands with esterases activity were observed at 12, 84 and $192 \mathrm{~h}$, showing a molecular weight of 37,45 and $50 \mathrm{kDa}$, respectively. 


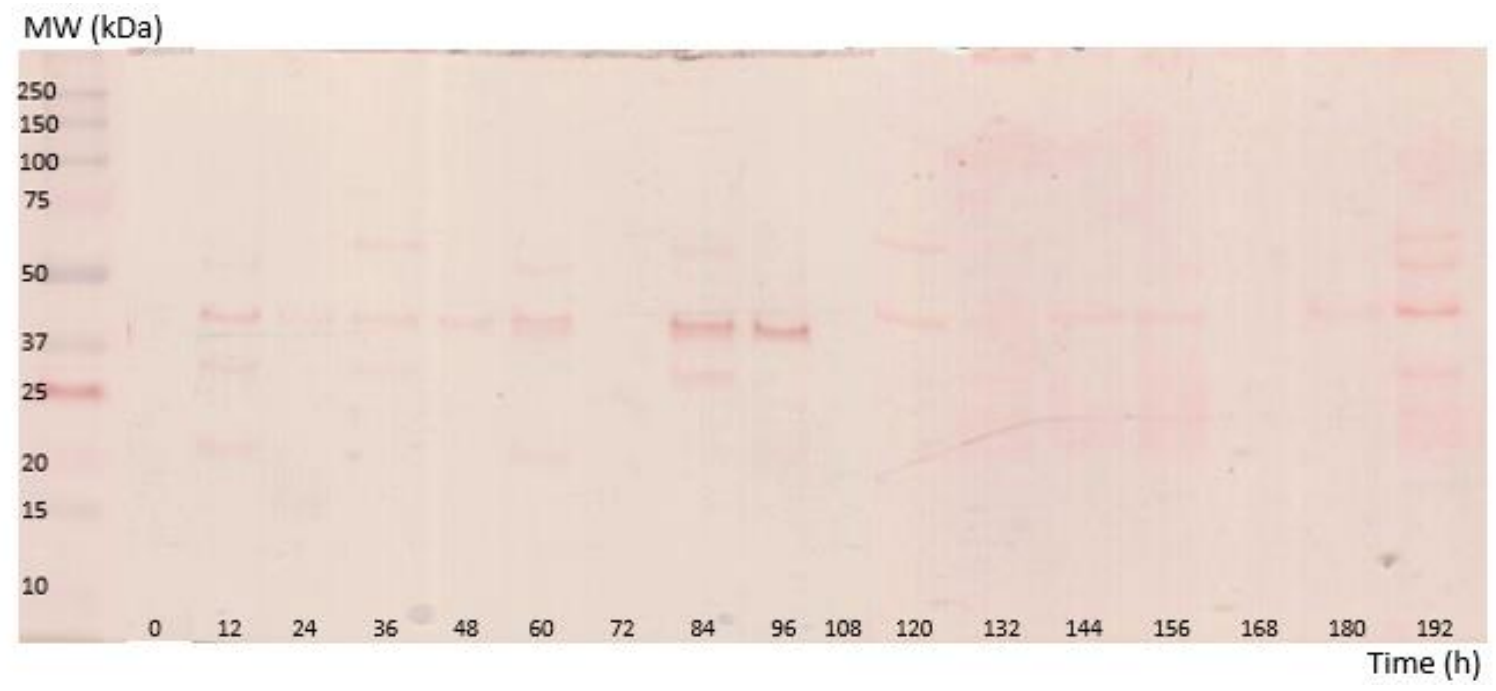

Fig. 3. Esterases zymogram of $F$. culmorum grown in medium containing glucose in submerged fermentation.

The esterases zymogram of the medium containing $1500 \mathrm{mg}$ of DEHP/L (Fig. 4) showed 7 bands after $24 \mathrm{~h}$ with a molecular weight of approximately 20, 23, 25, 37, 45, 75, and 140 $\mathrm{kDa}$, which was observed during the fermentation period. After $120 \mathrm{~h}$ increased the intensity of the bands with esterase activity

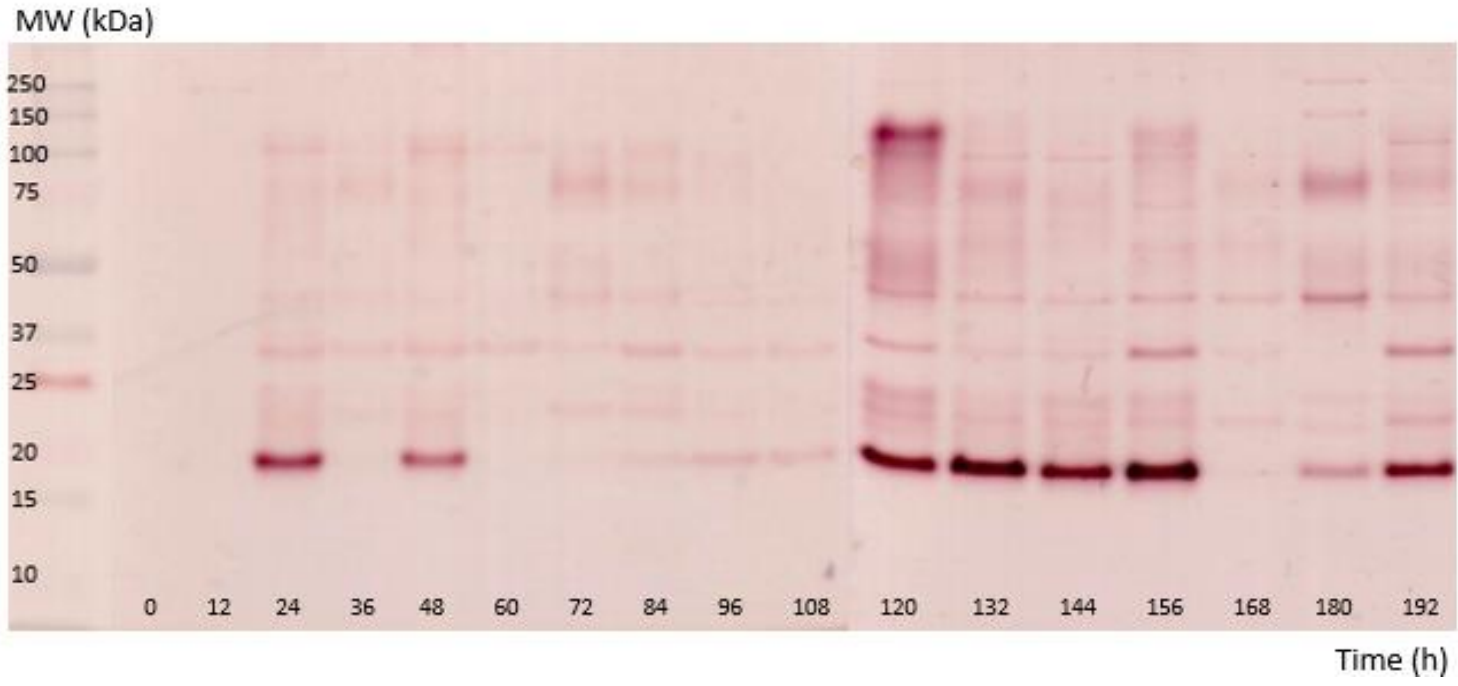

Fig. 4. Esterases zymogram of $F$. culmorum grown in medium supplemented with $1500 \mathrm{mg}$ of $\mathrm{DEHP} / \mathrm{L}$ in submerged fermentation.

Figure 5 shows an esterases zymogram of $F$. culmorum grown in medium containing 2000 mg of DEHP/L. A band with esterases activity of $45 \mathrm{kDa}$ approx. was observed after $24 \mathrm{~h}$. This band activity was showed during the fermentation period. Three bands of the growth 
activity were observed at different molecular weights $(23,37,45,70, \mathrm{kDa}$ approximately) after $36 \mathrm{~h}$. The zymogram showed bands of 23, 45 and $150 \mathrm{kDa}$ approximately between $108 \mathrm{~h}$ and $192 \mathrm{~h}$.

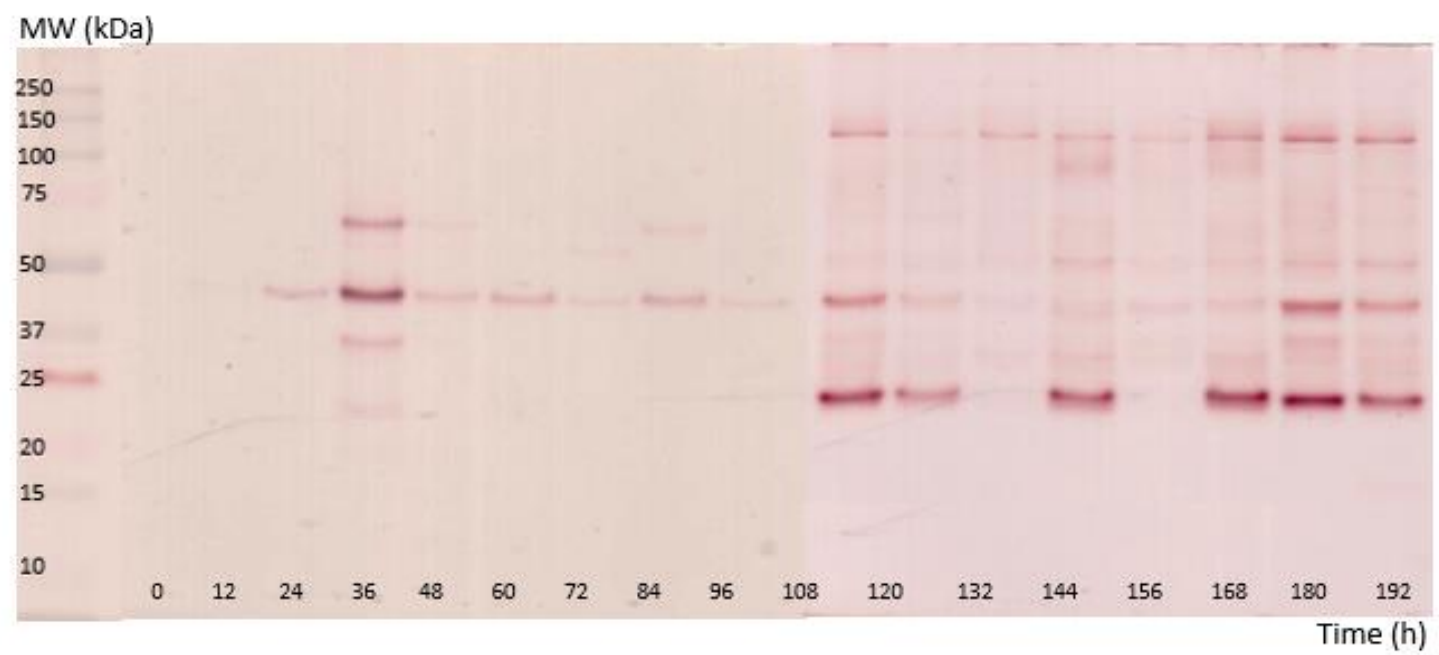

Fig. 5. Esterases zymogram of $F$. culmorum grown in medium supplemented with $2000 \mathrm{mg}$ of DEHP/L in submerged fermentation.

\subsection{Zymography analysis in cultures grown in solid-state fermentation}

Figure 6 shows the zymogram with esterase activity of $F$. culmorum grown in a medium containing glucose as a carbon source. A band with esterase activity was observed with a molecular weight of approximately $55 \mathrm{kDa}$ after $24,60,108,120,144,180$ and $182 \mathrm{~h}$ of incubation. Two esterase activity bands were observed with a molecular weight of $150 \mathrm{kDa}$ approx. between 60 and $72 \mathrm{~h}$ of incubation. The greatest activity of esterases was showed at $108 \mathrm{~h}$ of incubation. 


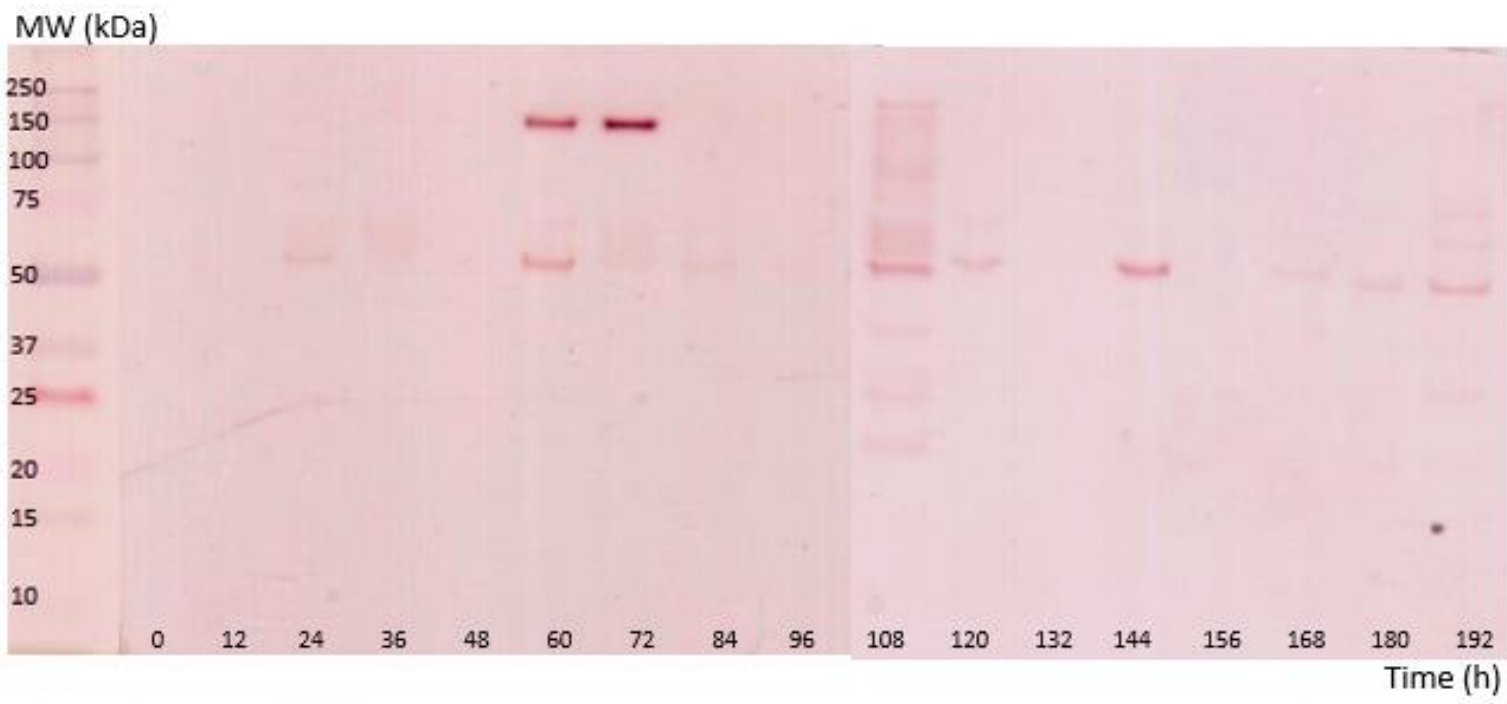

Fig. 6. Esterases zymogram of $F$. culmorum grown in medium containing glucose in solidstate fermentation.

The esterases zymogram of $F$. culmorum grown in medium supplemented with $1500 \mathrm{mg}$ of DEHP/L showed 2 bands with esterase activity with a molecular weight of approximately 45 and $70 \mathrm{kDa}$, respectively, between $60 \mathrm{~h}$ and $156 \mathrm{~h}$ of incubation (Fig. 7). Four different bands were observed with different molecular weights (20,25, 45 y $55 \mathrm{kDa}$ approximately) after $60 \mathrm{~h}$ of incubation. A band with esterase activity was observed at $156 \mathrm{~h}$ with a molecular weight of $150 \mathrm{kDa}$ approximately.

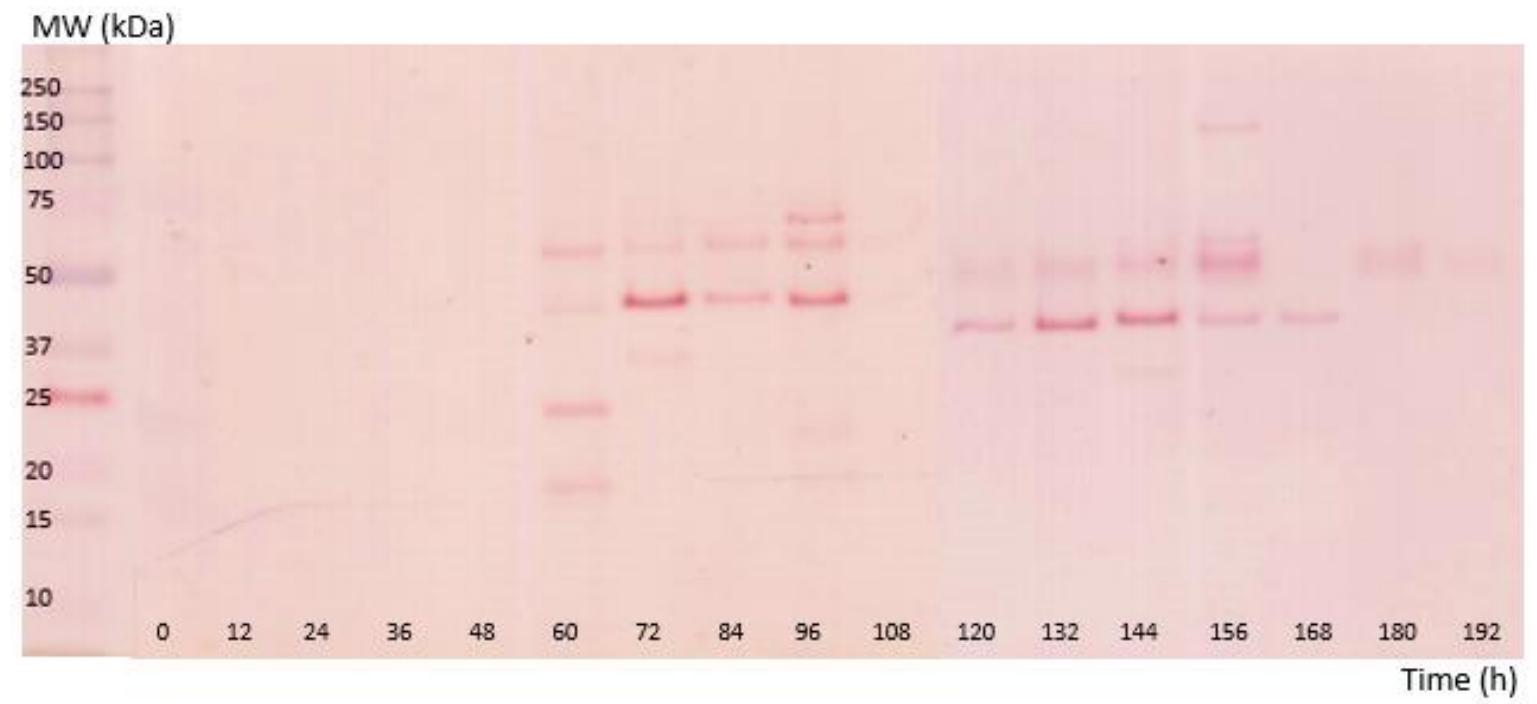

Fig. 7. Esterases zymogram of $F$. culmorum grown in medium supplemented with $1500 \mathrm{mg}$ of DEHP/L in solid-state fermentation. 
Figure 8 shows esterases zymogram of $F$. culmorum grown in medium supplemented with $2000 \mathrm{mg}$ of DEHP/L. 8 bands were observed with esterase activity (20, 23, 25, 37, 45, 55, $75,100 \mathrm{kDa}$ approximately) between 12 and $192 \mathrm{~h}$ of incubation. A band of $250 \mathrm{kDa}$ approximately was observed after 36, 48, 72, 120, 156 and $168 \mathrm{~h}$ of incubation.

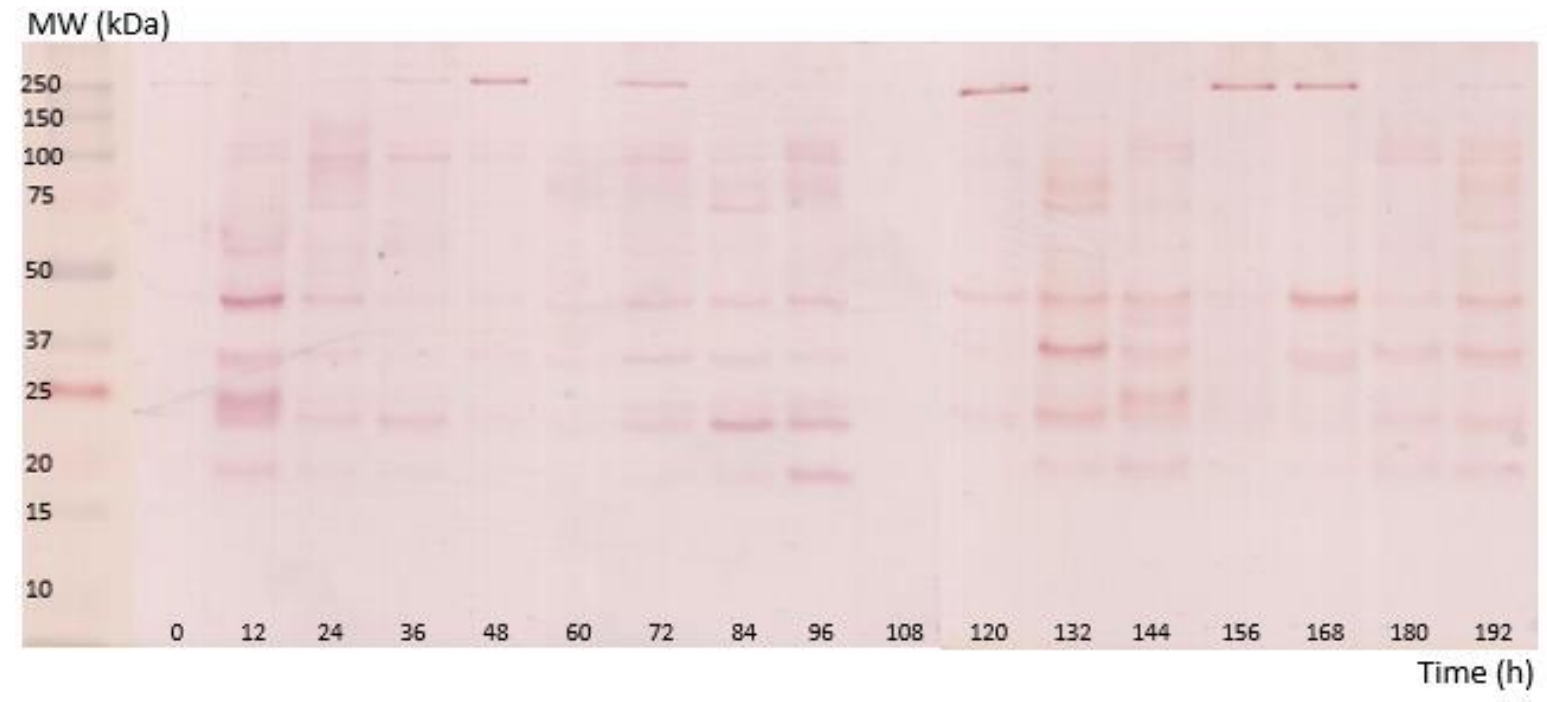

Fig. 8. Esterases zymogram of $F$. culmorum grown in medium supplemented with $2000 \mathrm{mg}$ of DEHP/L in solid-state fermentation.

\section{DISCUSSION}

In the present study, two fermentation systems were used for the growth of $F$. culmorum (submerged fermentation and solid-state fermentation). F. culmorum showed higher enzymatic activity in solid-state fermentation than in submerged fermentation. ViniegraGonzalez et al. (2003) reported that the growth and enzymatic activity of filamentous fungi increased in solid-state fermentation conditions. Macedo \& Pio (2005) reported that glucose repressed esterases enzymatic activity in Fusarium oxysporum grown in medium containing glucose as sole carbon and energy source. The results obtained in the present research showed that the presence of glucose as a carbon and energy source, did not affect the esterases activity of $F$. culmorum.

Luo et al. (2012) used a esterase enzyme produced by Fusarum sp in the dimethyl terephthalate degradation, which showed a molecular weight of $45 \mathrm{kDa}$ approx. Other bands with esterase activity were also observed with different molecular weights, possibly isoforms, of these proteins.

It has been reported that $F$. culmorum used DEHP (500 and $1000 \mathrm{mg} / \mathrm{L}$ ) as carbon and energy source and showed more esterase enzymatic activity at a higher DEHP concentration (Ahuactzin-Pérez et al., 2016). In the present research, F. culmorum showed higher enzymatic activity in those media supplemented with high DEHP concentrations 
(2000 $\mathrm{mg} / \mathrm{L}$ in submerged fermentation and $1500 \mathrm{mg} / \mathrm{L}$ in solid-state fermentation). Furthermore, the growth of this organism was not inhibited by such DEHP concentrations.

These results showed that esterases of $F$. culmorum were induced in media supplemented with DEHP. The addition of high concentrations of DEHP induced a high number of isoforms of esterases with diferent molecular weight.

\section{ACKNOWLEDGMENTS}

This work was carried out during a research stay (summer vacation) of BSc students from different Mexican Universities, at the Research Centre for Biological Sciences (CICB) of the Universidad Autónoma de Tlaxcala (Mexico). We thank the Programa Delfin and the Academia Mexicana de Ciencias committees for the support granted to the BSc students. We also thank for the scholarship provided during the summer vacation to some of the BSc students by their corresponding universities.

\section{CONFLICT OF INTEREST}

The authors declare that they have no conflict of interest.

\section{REFERENCES}

Adame-García J., Trigos-Landa A. R., Iglesias-Andren L.G., Flores-Estevez N. \& LunaRodriguez M. (2011). Variaciones enzimáticas y patogénicas de Fusarium spp. Asociadas con la pudrición de tallo y raíz de vainilla. Tropical and Subtropical Agroecosystems. 13: 299-306.

Aguilar-Alvarado Y., Báez S.R., Martínez C.C., Ahuactzin P.M., Cuamatzi M.M. \& Sánchez C. (2015). Mycelial growth and enzymatic activities of fungi isolated from recycled paper wastes grown on Di(2-ethylhexyl) phthalate. Polish Journal of Environmental Studies. 24(5): 1897-1902.

Ahuactzin-Pérez M., Tecuitl-Beristain S., García-Dávila J., González-Pérez M., GutiérrezRuíz M. C. \& Sánchez, C. (2016). Degradation of di(2-ethyl hexyl) phthalate by Fusarium culmorum: Kinetics, enzymatic activities and biodegradation pathway based on quantum chemical modelingpathway based on quantum chemical modeling. Science of the Total Enviroment. 566-567, 1186-1193.

Castro-Ochoa D., Peña-Montes C. \& Fárres A. (2010). Producción y características de cutinasas: Una alternativa interesante para biocatálisis a nivel industrial. Revista Especializada en Ciencias Químico-Biológicas. 13(1): 16-25.

Gao DW, Wen ZD (2015). Phthalate esters in the environment: A critical review of their occurrence biodegradation, and removal during wastewater treatment processes. Science of The Total Environment. 541: 986-1001. 
Karpushova A., Brummer F., Barth S., Lange S., \& Schmid R.D. (2005). Clonning, recombinant expression and biochemical characterisation of novel esterases from Bacillus sp. Asociated with the marine sponge Aplysina aerophoba. Applied Microbiology and Biotechnology. 67:59-69.

Leammli UK. (1970). Cleavage of Structural Proteins during the Assembly of the Head of Bacteriophage T4. Nature. 227: 680-685.

Macedo GA. \& Pio TF. (2005). A rapid screening method for cutinase producing microorganisms. Brazilian Journal of Microbiology. 36(4): 388-394.

Daiem M.M.A., Rivera-Utrilla J., Ocampo-Pérez R., Méndez-Díaz J. D. \& Sánchez-Polo M. (2012). Environmental impact of phthalic acid esters and their removal from water and sediments by different technologies-A review. Journal of Environmental Management. 109: 164-178.

Meng X., Niu G., Yang W. \& Cao X. (2015). Di(2-ethylhexyl) phthalate biodegradation and denitrification by a Pseudoxanthomonas sp. Strain. Bioresource Technology. 180: 356359.

Sánchez C., Téllez-Téllez M., Díaz-Godínez G. \& Moore D. (2004). Simple staining detects ultrastructural and biochemical differentiation of vegetative hyphae and fruit body initials in colonies of Pleurotus pulmonarius. Letters in Applied Microbiology. 38: 483487.

Viniegra-González G., Favela-Torres E., Aguilar C.N., Romero-Gómez S.J., Díaz-Godínez G. \& Augur C. (2003). Advantages of fungal enzyme production in solid state over liquid fermentation systems. Biochemical Engineering Journal. 13:157-167.

Luo, Z.H., Wu, Y.R., Chow, R.K.K., Luo, J.J., Gu, J.D. \& Vrijmoed, L.L.P. (2012). Purification and characterization of an intracellular esterase from a Fusarium species capable of degrading dimethyl terephthalate. Process Biochemistry. 47: 687-693. 